\title{
Historical and Institutional Determinants of Universities' Role in Fostering Entrepreneurship
}

\author{
Alexander Chepurenko ${ }^{\text {a }}$ \\ Professor of Economic Sociology, achepurenko@hse.ru
}

Maria Kristalova

Postdoctoral Fellow, Chair of Business Dynamics, Innovation and Economic Change ${ }^{\mathrm{b}}$; Affiliated Researcher, Chair of Economics of Innovation and Structural Change ${ }^{c}$, maria.kristalova@uni-jena.de

\section{Michael Wyrwich ${ }^{\mathrm{d}}$}

Associate Professor for Small Business \& Entrepreneurship, Innovation Management \& Strategy, m.wyrwich@rug.nl

a National Research University Higher School of Economics, 101000 Myasnitskaya str., 20, Moscow, Russian Federation

${ }^{\mathrm{b}}$ Friedrich Schiller University Jena, Carl-Zeiss-Strasse 3, 07743 Jena, Germany

' University of Bremen, Bibliothekstraße 1, 28359 Bremen, Germany

${ }^{d}$ University of Groningen, Nettelbosje 2, 9747 AE Groningen, PO Box 800, 9700 AV Groningen, Netherlands

\begin{abstract}
$\mathrm{I}$ nstitutions play a key role in building entrepreneurial ecosystems (EEs). However, the academic literature does not well represent the historical roots of these institutions and most works are devoted to developed countries. This article examines the institutional conditions for the development of scientific and entrepreneurial activities at universities in the context of the transition to a market economy. It considers the «path dependence» (mentality and

infrastructure inherited from the past), as well as specific mechanisms for regulating the interaction of universities and other subjects of EE developed during the transition period. Such an approach allows us to assess the potential of universities for the development of entrepreneurship in countries with a transition economy and the impact of historical development paths upon the current structural conditions and the specific features of the EE.
\end{abstract}

Keywords: entrepreneurial ecosystems; transition; entrepreneurship; universities; institutions

Citation: Chepurenko A., Kristalova M., Wyrvich M. (2019) Historical and Institutional Determinants of Universities' Role in Fostering Entrepreneurship. Foresight and STI Governance, vol. 13, no 4, pp. 48-59. DOI: 10.17323/25002597.2019.4.48.59 
A lthough the concept is not new, there is still a growing amount of literature on entrepreneurial ecosystems [Cavallo et al., 2018; Ghio et al., 2019; Roundy, 2017; Roundy, Fayard, 2019]. The theoretic foundation of the entrepreneurial ecosystem (EE) concept is grounded in the literature on regional innovation systems, academic spin-offs, the triple helix model, and also in the literature on the interplay between institutional context and entrepreneurship. However, the theoretical richness of most of the literature is "tuned" to established Western market economies. Thus, to become relevant for transitional economies, it should be 'reframed' in the context of the dominant institutional environments that are to a significant extent predetermined by the former development and partially by the institutional traps of the transition itself in these countries. There are, however, only some exceptional attempts in the literature to explore the entrepreneurial ecosystems of some Central and Eastern European (CEE) economies and the Community of Independent States (CIS).

In general, the transition economies provide a picture of the huge differences in the quality of higher education and the development of market and democratic institutions, which might play an important role in the contemporary structure and embeddedness of the EE in these societies. The socialist mental and infrastructural legacy should be still taken into consideration when speaking about the interplay between actors in the EE (people, institutions) who reuse and recombine their "socioeconomic heritage" as measured by experience, network relationships, and social capital within EEs. This context helps one understand whether and how such human capital accelerators like universities can promote entrepreneurial activities and enrich EEs in transition.

The entrepreneurial patterns across transitional economies are quite different: The Global Entrepreneurship Monitor (GEM) shows lower levels of entrepreneurship in Russia compared to other transition economies. ${ }^{1}$ Russia compared to CCEs demonstrated an overall GEI underperformance by 1.8 times (Table 1) [Acs et al., 2018]. Such low values provide a strong indication that the current institutional environment hinders potential Russian entrepreneurs. Existing entrepreneurs are more often driven by necessity than by opportunity, the businesses either do not intend to grow or do not have the respective capacity and exhibit great distance from the world technological frontier. Operating on a large domestic market, entrepreneurs do not intend to enter the global market which, in turn, is another reason for the low level of innovativeness.
One reason for the existing bottlenecks in Russia's EE could be a distinct institutional environment, which is a mix of new institutions and actors, which emerged over the past 30 years, and the arrangement of older institutions (norms, values) inherited from the Soviet period. In particular, the structure, corporate culture and embeddedness of local universities in the emerging EE could explain different level of innovativeness of entrepreneurship and, thus, different outcomes of entrepreneurial development there.

This paper aims to describe the peculiarities of entrepreneurship relevant in post-socialist economies and its implications for the development of entrepreneurial ecosystems. We focus on Russia to understand the interplay between the (re)-emergence of entrepreneurship and the evolution of EE. We illustrate how the (re)emergence of entrepreneurship in the transition process affected the EE and its bottlenecks. ${ }^{2}$

\section{The EE Approach and Institutions}

There are several definitions of the concept entrepreneurial ecosystems (see Table 2). The literature on EE is closely related to the discourse on innovation, including the early studies on innovation systems, the debate around territorial innovation milieus such as industrial districts, clusters, and technopoles; the triple helix model, and, more recently, the literature on entrepreneurial ecosystems [Zahra, Nambisan, 2012].

The EE approach adopts a multi-level perspective by stressing self-perpetuating mechanisms, close relationships, interdependencies, supporting effects, and forward and backward linkages among the elements. Furthermore, the EE approach clearly distinguishes between the entrepreneurial environment (ecosystem) and the entrepreneurial outcomes. Of the different kinds of entrepreneurial outcomes, the EE focuses on those opportunity recognition activities that are likely to result in ambitious start-ups with high growth potential. The performance of the EE is determined by the interplay of the entrepreneur, the organizations, and the institutions [Alvedalen, Boschma, 2017; Spigel, 2017; Stam, 2015] where the entrepreneur is the most important agent assuming his several roles (e.g., leader, mentor, and investor).

Generally, networks of different institutions are needed to trigger research development and innovation processes, with networking and cooperation supporting innovative activities at the regional level [Hewitt-Dundas, 2013]. There are three possible network configurations fostering regional entrepreneurial ecosystems, namely science-led, industry-led, and

\footnotetext{
In 2014 , only $8.63 \%$ of Russian population between $18-64$ years were entrepreneurially active, $50 \%$ or more below other (post-)transition economies: Hungary (16.93\%), Romania (18.35\%), Poland (15.99\%), Lithuania (18.62\%), Estonia (15.03\%), Slovakia (18.20\%), or even Kazakhstan (20.63\%).

See the paper by Pager et al. in this issue.
} 
Table 1. GEI Component Values: Comparisons between Russia and Some CEE Countries

\begin{tabular}{|l|l|l|}
\hline \multicolumn{1}{|c|}{ Indicator } & \multicolumn{1}{c|}{ Russia } & CEE average \\
\hline Opportunity perception & 0.128 & 0.406 \\
\hline Start-up opportunity & 0.219 & 0.548 \\
\hline High growth & 0.355 & 0.568 \\
\hline Internationalization & 0.055 & 0.715 \\
\hline Risk acceptance & 0.193 & 0.392 \\
\hline Cultural support & 0.162 & 0.334 \\
\hline Product innovation & 0.158 & 0.321 \\
\hline Risk capital & 0.186 & 0.383 \\
\hline $\begin{array}{l}\text { Note: The group of CEEs Russia is compared to includes Croatia, Czech } \\
\text { Republic, Estonia, Hungary, Latvia, Lithuania, Poland, Slovakia, and } \\
\text { Slovenia. } \\
\text { Source: compiled by the authors using [Acs et al., 2018]. }\end{array}$ \\
\hline
\end{tabular}

policy-led (Table 3) [Diez, 2000; Schätzl, 1999]. From this point of view, Russia represents a rather unique fourth case where the main driver of the local entrepreneurial ecosystem was a large business supported by the state to establish among other things a new university that could act as a hub attracting students and entrepreneurs to form an innovative environment (Skolkovo) or by regional authorities (Innopolis in Tatarstan).

The EE approach stands in line with a larger vein of literature suggesting that regional differences in place-based conditions imply huge spatial variation of entrepreneurial activities [Acs, Storey, 2004; Acs et al., 2014; Fritsch, Storey, 2014; Sorenson, 2017]. The range of factors influencing entrepreneurship that are identified in this literature comprises agglomeration forces, industry structure, regional knowledge, and local entrepreneurship cultures and institutions. In large countries like Russia, the variety of these factors might be especially great [Chepurenko et al., 2017].

An important part of the regional knowledge stock is represented by universities which are therefore also a key actor of EEs. Universities of the third generation [Etzkowitz, 2001, 2003; Thursby, Thursby, 2002; Ulhøi et al., 2012] might play an especially important role for the absorption, storage, and diffusion of knowledge and are also engaged in the generation of new knowledge within the triple helix model approach. First of all, they provide innovation-related inputs and contribute to the regional stock of human capital [Schubert, Kroll, 2016] that plays an important role in identifying entrepreneurial opportunities. Second, entrepreneurial universities as institutional players are key actors - brokers and gatekeepers - in local innovation systems [Fritsch et al., 2018; Graf, 2011; Kauffeld-Monz, Fritsch, 2013].

The EE approach is also rooted in the culture and institutional tradition [North, 1990] of entrepreneurial research. The key formal institutions that affect the supply and level of productive entrepreneurship are property rights enforcement, savings policies, taxation, and labor market regulation [Elert et al., 2017] as well as the structure and innovation potential of such local drivers as universities. An informal institution that determines the level of entrepreneurship is the extent to which entrepreneurship is socially accepted [Beugelsdijk, 2007; Mueller, Thomas, 2001; Smallbone, Welter, 2006]. An entrepreneurial culture is typically defined as the collective programming of the mind in favor of entrepreneurship [Beugelsdijk, 2007; Freytag, Thurik, 2007]. Our own research shows that entrepreneurial culture can be highly persistent over time [Fritsch, Wyrwich, 2014, 2017a; Stuetzer et al., 2018; Wyrwich, 2012] and differ even among different regions of the same country, such as West and East Germany [Fritsch et al., 2014; Wyrwich, 2013, 2015]. Institutions, which play an important role, might be structured differently. However, these differences are the result of a historical development or are path dependent.

\section{The Institutional Context for Entrepreneurial Ecosystems in Post-Socialist Economies and Russia in Particular}

Transition reforms in former planned economies have been believed to lead to better firm performance, resulting mainly from structural transformations, the support of market institutions, and openness to international trade and investment. The transition paths were not uniform across all countries undergoing the transformation. Empirical evidence indicates that the transition path of Russia and some other CIS countries was different from CEE countries.

It is widely accepted that the legacy effects of the socialist past determine entrepreneurship long after the start of the systemic transition [Estrin, Mickiewicz, 2011; Manolova et al., 2008; McMillan, Woodruff, 2002; Welter, 2005]. This is in line with the general literature on the distinctiveness of entrepreneurship in transition countries [Ovaska, Sobel, 2005; Smallbone, Welter, 2001; Welter, 2005].

However, over the course of the systemic transition itself, a set of country-specific factors and even institutional traps [Polterovich, 2017] occurred which predetermined a growing variety of post-transitional institutional settings in different transitional countries and regions [Aidis, Welter, 2008a, 2008b; Estrin, Mickiewicz, 2011; Welter, 2011]. Therefore, some authors argue in favor of a 'diverging paths' approach [Sauka, Chepurenko, 2017] differentiating the former socialist economies according to the inclusive vs. extractive institutions concept by Acemoglu and Robinson [Acemoglu, Robinson, 2012] as well as dominant types of entrepreneurial activity [Sauka, Welter, 2007].

Weaker institutions, path dependence, and vested interest groups have been argued to define the spe- 
Table 2. Definitions of Entrepreneurial Ecosystem

\begin{tabular}{|l|l|}
\hline \multicolumn{1}{|c|}{ Definition } & \multicolumn{1}{|c|}{ Source } \\
\hline $\begin{array}{l}\text { Dynamic, institutionally embedded interaction between entrepreneurial attitudes, ability, and aspirations by } \\
\text { individuals, which drives the allocation of resources through the creation and operation of new ventures }\end{array}$ & $\begin{array}{l}\text { [Ács et al., } \\
2014]\end{array}$ \\
\hline An interdependent set of actors that is governed in such a way that it enables entrepreneurial action & [Stam, 2014] \\
\hline $\begin{array}{l}\text { Dynamic community of inter-dependent actors (entrepreneurs, supplies, buyer, government, etc.) and system-level } \\
\text { institutional, informational and socioeconomic contexts }\end{array}$ & $\begin{array}{l}{[\text { Audretsch, }} \\
\text { Belitski, 2017] }\end{array}$ \\
\hline Source: compiled by the authors using the abovementioned sources. & \\
\hline
\end{tabular}

cific transition trajectory of Russia [Aidis et al., 2008; Bessonova, Gonchar, 2015; Bruton et al., 2010; Gurvich, 2016]. More specifically, institutional traps [Polterov$i c h, 2017]$ which occurred as a result of the voucher privatization there [Boycko et al., 1995] led to a massive distortion of market signals and manifested itself in an exorbitant proportion of the state-owned enterprises (SOEs), a policy of industrial paternalism (e.g. soft budget constraints and a non-functioning creative destruction mechanism), which implies the unreasonable backing of inefficient industries and companies as well as an inefficient public administration mechanisms, weak property rights protection, the vulnerability of property, and an ongoing struggle for rents as the key institutional constraints [Gurvich, 2016]. This resulted in a dominant role of 'predatory entrepreneurs' [Feige, 1997] and of 'unproductive entrepreneurship' [Baumol, 1990] in the EE. A broad consensus in the literature exists that Russia's current deficiencies in its entrepreneurial activity can be explained by institutional imperfections or obstacles, such as high borrowing costs, red-tape, high levels of corruption, insufficient rule of law, and issues with property rights [Chepurenko et al., 2017; Volchek et al., 2013; Yukhanaev et al., 2015; Zhuplev, Shtykhno, 2009].

In recent years, a continuous decline of Russian democratic institutions has been taking place [Lamberova, Sonin, 2018] and coincided with an all-encompassing trend of political and economic centralization [Alexeev, Mamedov, 2017], which probably also had an impact upon the emergence of regional EEs in a negative way.

Szerb and Trumbull [Szerb, Trumbull, 2018] analyze Russia's EE over the period of 2006-2016 considering both its individual and institutional dimensions and conclude that the country lags significantly behind other transition as well as similar efficiency-driven economies. Informal investment, obsolete technologies, and low levels of internationalization as well as the lack of opportunity perception and startup skills within the population are among the factors still standing in the way of building a successful EE.

Although the literature shows a variety of $\mathrm{EE}$ on national, regional, and even global levels, the best studied are regional EEs, most of which are located in developed economies: Silicon Valley, Route 158, Boston, and Stanford clusters in the US, Aalto area near Helsinki, Finland, London Roundabout and the Thames Valley Business hub in Berkshire, England [Audretsch, Belitski, 2017], the Malopolskie region in Poland [OECD, 2019], and Skolkovo in Moscow. The favorable EE conditions of the region include a growing number of start-ups in the digital economy, accelerators, and venture capital funds as well as effective knowledge transfer centers (KTCs).

Using Estonian data, Velt et al. [Velt et al., 2018] identify seven key factors impacting the launch of global startups within a successful EE in transition economies: entrepreneurial talent, informal loans, bootstrapping, leadership, knowledge, engagement ser-

\section{Table 3. Types of Regional Entrepreneurial Networks}

\begin{tabular}{|l|l|l|}
\hline \multicolumn{1}{|c|}{ Type of network } & \multicolumn{1}{|c|}{ Description } & \multicolumn{1}{c|}{ Examples } \\
\hline Science-led & $\begin{array}{l}\text { Universities or research institutions trigger regional development } \\
\text { with a particular focus on knowledge transfer and innovation }\end{array}$ & $\begin{array}{l}\text { Silicon Valley, Route 128 (US) or } \\
\text { Cambridge and Oxford in the UK }\end{array}$ \\
\hline Industry-led & $\begin{array}{l}\text { Research-intensive large firms are the innovation hub, with close } \\
\text { links to university research }\end{array}$ & $\begin{array}{l}\text { Volkswagen automobile cluster in } \\
\text { Wolfsburg (Germany) }\end{array}$ \\
\hline Policy-led & $\begin{array}{l}\text { To be observed in regions where policymakers initiated successful } \\
\text { science parks }\end{array}$ & Silicon Glen (Scotland) \\
\hline \multicolumn{2}{|l}{ Source: compiled by the authors. }
\end{tabular}


vices, and networks. For their growth, worker talent, formal equity (venture capital and angel investors), bootstrapping, professional services and intermediaries play an important role as well. ${ }^{3}$ Heller [Heller, 2013] attempts to evaluate the Russian innovation ecosystem and concludes that while there is some rapid development, for instance in infrastructure, the culture that was formed during the Soviet period remains the major drawback.

The current EE in Russia has shown shortages of coherent reforms of the R\&D and innovation systems since the early 1990s [Gokhberg, 2004; Gokhberg, Kuznetsova, 2011], all of which results in a low level of innovation spillovers from universities. In some recent years, for instance, the Russian government and regional authorities tried to rebuild the regional EEs of Moscow, St. Petersburg, Tomsk, Tatarstan, and some other regions. The first nationwide cluster program was launched in 2012, with support for pilot innovative clusters being the first step [Kutsenko, Meissner, 2013]. However, the process of developing and implementing special economic zones (SEZs) and industrial parks in Russia has not delivered the desired results so far [Sosnovskikh, 2017].

Other elements in promoting regional EE include the technology parks, business incubators, technology transfer centers, prototyping and design centers, engineering centers, subsidized participation at fairs, and educational support. For instance, in his 2019 message to the Federal Assembly, President Putin announced that 15 scientific and educational centers, which are designed to integrate all levels of education and capabilities of scientific organizations and businesses at the regional level to boost technological development in Russian regions are supposed to be founded in the next three years. Three of these centers are to be launched already in 2019. However, all these attempts are typically top-down, both the role and motivation of industry and universities to participate are still scarcely researched.

Therefore, in the following section we would like to describe the role of the higher education institutions in Russia as prospective core elements of regional EEs and the historically rooted institutional constraints.

\section{Russian Universities as Actors in EEs}

A modern strand of an entrepreneurial research defines entrepreneurial universities, around which the EEs evolve, as key elements in promoting regional economic growth [Fuster et al., 2019; Guerrero et al., 2016]. Accompanying this development, spin-off entrepreneurship, patenting, licensing and other activities of knowledge and technology transfer from universities to the private sector have attracted con- siderable scholarly attention [Astebro, Bazzazian, 2011; Gianiodis et al., 2016; Meissner, Shmatko, 2017; Perkmann et al., 2013; Rothaermel et al., 2007]. An important part of this literature has sought to explain the institutional differences in technology transfer [Bijedic et al., 2015; Bruneel et al., 2010; Grimpe, Fier, 2010; Leydenm, Link, 2013]. For example, it has been found that the level of industry funding and the nature of research within the university [O'Shea et al., 2005; Powers, McDougall, 2005], the size and quality of the research faculty [Di Gregorio, Shane, 2003; O'Shea et al., 2005], and a university's entrepreneurial tradition [D'Este, Perkmann, 2011; Lockett et al., 2005; Shane, 2004] all are strong predictors of the probability and number of spin-off companies.

Moreover, as it is shown in the literature, a significant share of knowledge flows related to the creation and commercialization of novel ideas occurs in geographically limited areas [Audretsch, 2003; Hassink, Wood, 1998; Keeble et al., 1998]. Our own research in this realm shows that knowledge spillovers within universities, but also into the region, are conducive for entrepreneurship [Fritsch, Wyrwich, 2017b; Goethner, Wyrwich, 2017]. This finding is in line with the knowledge spillover theory of entrepreneurship (e.g., [Carlsson et al., 2009]). That is knowledge generated within universities and commercialized via the establishment of entrepreneurial firms.

The empirical research on the position of universities and their prominent role [Korosteleva, Belitski, 2017] within entrepreneurial ecosystems in transitional economies has been rather scarce so far. Although some CEE regions are already successful in implementing an entrepreneurial university - a few examples include Entrepreneurship Home ${ }^{\otimes}$ and IdeaLab at the University of Tartu as well as Mectory at the Tallinn University of Technology (both in Estonia) or the Startup Campus at the Technological University of Budapest (in Hungary) - a truly working knowledge transfer through entrepreneurial universities seems to be a general bottleneck of EEs there. The patterns of research commercialization in transition economies (Azerbaijan, Belarus and Kazakhstan) are somewhat different from established market economies: the existence of technology transfer offices and other institutions does not correlate with research commercialization, contrary to the direct industrial funding of university research [Belitski et al., 2019]. This might be caused by institutional inertia (traditionally, the higher education structure and objectives in the former USSR were different than in the West) as well by some institutional arrangements which occurred already during the systemic transition.

First of all, it is the scope and quality of research at Russian universities. Since the beginning of the in-

${ }^{3}$ See also Trabskaja and Mets in the current issue. 
dustrialization policy under Stalin, there has been a strong differentiation between higher schools as institutions to enable the mass education of engineers for huge Soviet plants and construction projects, and research institutes of the Academy of Sciences where highly qualified researchers worked. R\&D activities at the universities were restricted, an institutional separation of higher education from research persisted over the decades [Froumin et al., 2014; Smolentseva et al., 2018]. Only exceptionally, the oldest centers like St. Petersburg and Moscow State universities obtained a more or less developed research infrastructure. In early 1960s, the newly established Novosibirsk State University joined this small group of researching universities. Besides, there were some technical universities (Bauman higher technical school $^{4}$, Moscow Physical-Technical higher school, etc.) where applied research was an obligatory part of education. In recent years, the aforementioned Program 5-100 of the Russian government ${ }^{5}$, partly supported the establishment of research and education clusters of excellence at about 25 universities, but it hardly changed the general situation among the approximately 1,150 other higher schools and universities. Taking into consideration the historical origins and the current context, most of the higher schools are simply not able to become triggers for regional EEs due to a lack of pioneering research units and qualified personal [Froumin et al., 2014; Gershman et al., 2018].

Second, it is the role of the historically overcentralized location of the leading research and education institutions. In the Russian Empire in the beginning of the $20^{\text {th }}$ century, there were only 12 universities, three of them on the territory of modern Ukraine, and one each in Estonia, Lithuania, Finland, and Poland. In Russia itself, there were only five universities - in St. Petersburg, Moscow, Kazan, Tomsk, and Saratov. This means that most of Russian regions had no established centers of research and education. Even now, about $30 \%$ of all Russian universities are located in the two capitals (approximately 270 in Moscow and another 90 or so in St. Petersburg). The majority of research institutes of the Russian Academy of Sciences and many EE infrastructure units (industrial parks, business incubators, engineering and prototyping centers etc.) are concentrated in Moscow and St Petersburg [Sivak, Yudkevich, 2017]. There, the partly overlapping networks of several universities, research institutes, and industrial enterprises form a synergetic effect and, thus, a dense regional EE. Outside of these capital cities, there are only a few 'research cities' (like Kazan, Tomsk, Tyumen, Novosibirsk, and so on.) where first-class universities and other institutions might form the core of a local EE [Aldieri et al., 2018].

After the collapse of the Soviet Union, universities in Russia were caught in a situation of high uncertainty and a lack of funding. Due to large problems with the higher education system during the 1990-2000s, the research equipment and education infrastructure even at the most advanced Russian universities were often old or outdated. Some of them try to avoid these constraints by focusing on promoting and funding a few centers of excellence, but under the current trend of the general reduction of state funding for education in the country and a lack of private donators who could fill in the financial gap, the innovation potential of most of Russian universities remains rather restricted [Gokhberg, Kuznetsova, 2011]. Ever since this transformation process started, fostering research commercialization became one of the priority issues for policymakers and the public authorities. Starting in the mid-2000s, some measures directed at underpinning the role of higher education institutions (HEI) within the EE were implemented in Russia [Gokhberg, 2004]. Federal and National Research Universities were established, innovative education programs (IEPs) were launched, and the so-called Program 5-100, which intended the inclusion of at least five Russian universities in international rankings, was launched in 2013. These measures were intended to strengthen the national innovation system [Gokhberg, Kuznetsova, 2011] and the position of the universities within EEs.

Third, the corporate culture of Russian universities, partly inherited from the past, partly established during the transition itself [Yudkevich, 2014], is another obstacle to impeding the transformation of them into crucial actors in regional EEs. It is known from the literature that to become a driver of the local $\mathrm{EE}$, the university should transform into a third generation or entrepreneurial university [Astebro, Bazzazian, 2011; Clark, 1998; Gianiodis et al., 2016; Meissner, 2018]. Unfortunately, most Russian higher schools and universities do not feel inspired to transform the organizational structure, corporate spirit, personal renewal, and so on. [Froumin et al., 2014].

Finally, important stakeholders of entrepreneurship at universities are students, both in form of an onsite-campus entrepreneurship and in form of an ITstartup activity, which play an important role in the development of regional entrepreneurship ecosystems, but also need to be supported by the latter during the initial stage. The entrepreneurial engagement of students in Russia (and some other CIS countries) is rather high: the proportion of potential entrepre-

\footnotetext{
${ }^{4}$ Current name is the Bauman Moscow State Technical University (BMSTU).

Program 5-100 is aimed at promoting a small group of universities to place in the top 100 universities in the world in their area of expertise.
} 
neurs (i.e., those who already try to start their own business) among students is $27 \%$, which is 6 percentage points higher than in the international sample, and the share of active entrepreneurs (i.e., those who already manage their own business) is up to $8 \%$. Compared to 2011, the number of potential entrepreneurs among Russian students increased by 5 percentage points [Bergmann, Golla, 2016]. These data do not reflect the character of the entrepreneurial activity of students (opportunity vs. necessity driven; innovative or rather on campus business activities etc.) but says much about the entrepreneurial spirit of young prospective entrepreneurs.

However, the engagement of the teaching staff of universities in entrepreneurial activity is very moderate. One of the reasons is the median age of universities' fellows. As a result of the degradation of science and education in early 1990s, younger cohorts left Russian universities and either moved to the commercial sector, public administration, or settled in the West [Korobkov, Zayonchkovskaya, 2012], therefore the age structure of a typical Russian university is dominated by older cohorts raised under the Soviet system who are not inclined to commercialize their research outputs.

One of the tools to establish an innovative entrepreneurial community within the universities was the governmental plan to enable educational institutions and their fellows to establish new small innovative ventures according to the Federal Law Nr. 217 adopted in 2009. Innovators received taxation preferences and universities received $33 \%$ of companies' stock capital, as well as the right to the intellectual property of start-ups. However, the initial enthusiasm soon declined. To compare, in 2010-2011 in Russia more than 1,300 small innovative enterprises (SIE) were established, in 2012-2013 - only about 1,000, in 2014-2015 slightly more than 350, while in 2016-2018 this figure was also about 350 , but within a three-year period. ${ }^{6}$ There were several typical problems that occurred and showed that the innovative potential of Russian universities to become triggers of regional EEs was very limited. First, it came out that it was an extremely complicated problem to identify the intellectual property as a contribution to share capital of the SIE. Second, universities' fellows were not ready to take responsibility for creating SIEs as founders or act as managers. Third, due to bureaucratic reasons, universities could not provide them rent for free most of the SIEs would rent rooms outside of the universities. Lastly, the rather few private business angels and venture capitalists were prepared to deal with start-ups led by novice entrepreneurs and supported by inexperienced innovation infrastructure officers of the universities. Thus, the entrepreneurial enthusiasm of students is not linked with the commercialization of know-how of teaching staff at most Russian universities.

Some additional reasons for this phenomenon are also evident: the primitive structure of the national economy does not support any demand for innovative start-ups, while high risks, weak or absent financial and legal support infrastructure, and a low level of horizontal networking between universities and industry in regional EEs [Bruneel et al., 2010; D'Este, Perkmann, 2011] shape additional constraints for academics and students motivated to create a commercial spin-off of their know-how.

\section{Conclusions and Implications}

Due to historical reasons and the transition experience, regional EEs in Russia are characterized by a weak institutional frame, the marginal role of innovations, a lack of horizontal cooperation between key stakeholders, and the restricted influence of universities upon regional EEs.

Although Russia has a high level of overall education and students' willingness to become entrepreneurs is rather high, a stronger embeddedness of universities into the EEs is required. To achieve this goal, in recent years the Russian government launched several initiatives to support the emergence of a group of world class universities and to promote entrepreneurship in academia. However, there are two groups of factors which are lowering the ability of higher education institutions to become important actors in regional EEs - first of all, this includes the rigid institutional framework (the low level of pioneering research activities, the weakness of an innovation support infrastructure within and on the periphery of the university, the lack of an entrepreneurial mindset among professors, etc.) and second, the unfavorable macro conditions (the low innovation absorption capability of the economy, the dominance of the state-owned large corporations on the domestic market, insecure property rights, and so on).

To support this positive trend, entrepreneurial research should focus on investigating cases of success of single university-led regional EEs in Russia and other CIS countries - to learn which strategies could be benchmarked and widespread. Moreover, a comparison of Russia with the CEE and other CIS countries would be of particular interest, as any entrepreneurial policy needs to be tailor-made to the specific regional and country-specific conditions. This includes the acceptance of the historical roots of these conditions which are similar in these countries. Thus, further research could, for instance, deal with the his-

${ }^{6}$ For more details see: https://mip.extech.ru/, access date 23.07.2019. 
torically evolved role of the Russian government with respect to scientific organizations and knowledge transfer [Gershman et al., 2018] to better understand some present-day bottlenecks of Russian regions' EEs.

In order to build a sustainable EE in Russia, the fostering of synergies between the EE actors, among them the university-business collaboration, is needed. The bridging role of alumni and practitioners as business angels and coaches should be supported. For this reason, tax reductions for business angels and private venture funds, including international ones, should be implemented. This could also strengthen the weak internationalization pillar of Russian EEs.

Another measure could be strengthening entrepreneurial education at universities. ${ }^{7}$ Further elements of the overall university strategy might be increasing the number of chairs in entrepreneurship, business incubators, and engineering and prototyping centers as well as attracting business representatives who would coach and mentor start-ups and promote entrepreneurial culture to help universities establish an EE from the bottom-up.

\section{References}

Acemoglu D., Robinson J.A. (2012) Why nations fail: The origins of power, prosperity, and poverty (1st ed.), New York: Crown Publishers.

Acs Z., Storey D. (2004) Introduction: Entrepreneurship and Economic Development. Regional Studies, vol. 38, no 8, pp. 871-877. DOI: 10.1080/0034340042000280901.

Acs Z.J., Autio E., Szerb L. (2014) National Systems of Entrepreneurship: Measurement issues and policy implications. Research Policy, vol. 43, no 3, pp. 476-494. DOI: 10.1016/j.respol.2013.08.016.

Acs Z., Szerb L., Lloyd A. (2018) Global Entrepreneurship Index 2018, Washington, D.C.: Global Entrepreneurship and Development Institute (GEDI).

Aidis R., Estrin S., Mickiewicz T. (2008) Institutions and entrepreneurship development in Russia: A comparative perspective. Journal of Business Venturing, vol. 23, no 6, pp. 656-672. DOI: 10.1016/j.jbusvent.2008.01.005.

Aidis R., Welter F. (2008a) Innovation and entrepreneurship: Successful start-ups and businesses in emerging economies (eds. R. Aidis, F. Welter), Cheltenham: Edward Elgar.

Aidis R., Welter F. (2008b) The cutting edge: Innovation and entrepreneurship in New Europe (eds. R. Aidis, F. Welter), Cheltenham: Edward Elgar.

Aldieri L., Kotsemir M.N., Vinci C.P. (2018) Knowledge spillover effects: Empirical evidence from Russian regions. Quality \& Quantity, vol. 52, no 5, pp. 2111-2132. DOI: 10.1007/s11135-017-0624-2.

Alexeev M., Mamedov A. (2017) Factors determining intra-regional fiscal decentralization in Russia and the US. Russian Journal of Economics, vol. 3, no 4, pp. 425-444. DOI: 10.1016/j.ruje.2017.12.007.

Alvedalen J., Boschma R. (2017) A critical review of entrepreneurial ecosystems research: Towards a future research agenda. European Planning Studies, vol. 25, no 6, pp. 887-903. DOI: 10.1080/09654313.2017.1299694.

Astebro B.T., Bazzazian N. (2011) Universities, Entrepreneurship and Local Economic Development // Handbook of Research on Entrepreneurship and Regional Development. National and Regional Perspectives (ed. M. Fritsch), Cheltenham (UK), Northampton, MA: Edward Elgar Pub.

Audretsch D.B. (2003) Innovation and Spatial Externalities. International Regional Science Review, vol. 26, no 2, pp. 167-174. DOI: $10.1177 / 0160017602250973$.

Audretsch D.B., Belitski M. (2017) Entrepreneurial ecosystems in cities: Establishing the framework conditions. Journal of Technology Transfer, vol. 42, no 5, pp. 1030-1051. DOI: 10.1007/s10961-016-9473-8.

Baumol W.J. (1990) Entrepreneurship: Productive, Unproductive, and Destructive. Journal of Political Economy, vol. 98, no 5, pp. 893-921.

Belitski M., Aginskaja A., Marozau R. (2019) Commercializing university research in transition economies: Technology transfer offices or direct industrial funding? Research Policy, vol. 48, no 3, pp. 601-615. DOI: 10.1016/j.respol.2018.10.011.

Bergmann H., Golla S. (2016) Unternehmertum an Hochschulen in Deutschland: Ergebnisse des Global University Entrepreneurial Spirit Students' Survey (GUESSS) 2016, St. Gallen: Universitat St. Gallen, Hochschule Fulda. Available at: http://www. guesssurvey.org/resources/nat_2016/GUESSS-Bericht-Deutschland-2016_30Sept2016.pdf, accessed 23.04.2019.

Bessonova E., Gonchar K. (2015) Bypassing weak institutions in a large late-comer economy. Journal of Institutional Economics, vol. 11, no 4, pp. 847-874.

Beugelsdijk S. (2007) Entrepreneurial culture, regional innovativeness and economic growth. Journal of Evolutionary Economics, vol. 17, no 2, pp. 187-210. DOI: 10.1007/s00191-006-0048-y.

Bijedic T., Maass F., Schröder C., Werner A. (2015) Der Einfluss institutioneller Rahmenbedingungen auf die Gründungsneigung von Wissenschaftlern an deutschen Hochschulen. IfM-Materialien, vol. 233. Bonn: Institut für Mittelstandsforschung.

See the paper by Zobnina et al. in this issue. 
Boycko M., Shleifer A., Vishny R. (1995) Privatizing Russia, Cambridge, MA., London: MIT Press.

Bruneel J., D'Este P., Salter A. (2010) Investigating the factors that diminish the barriers to university-industry collaboration. Research Policy, vol. 39, no 7, pp. 858-868. DOI: 10.1016/j.respol.2010.03.006.

Bruton G.D., Ahlstrom D., Li H.-L. (2010) Institutional Theory and Entrepreneurship: Where Are We Now and Where Do We Need to Move in the Future? Entrepreneurship Theory and Practice, vol. 34, no 3, pp. 421-440. DOI: 10.1111/j.15406520.2010.00390.x.

Carlsson B., Acs Z.J., Audretsch D.B., Braunerhjelm P. (2009) Knowledge creation, entrepreneurship, and economic growth: A historical review. Industrial and Corporate Change, vol. 18, no 6, pp. 1193-1229. DOI: 10.1093/icc/dtp043.

Cavallo A., Ghezzi A., Balocco R. (2018) Entrepreneurial ecosystem research: Present debates and future directions. International Entrepreneurship and Management Journal, vol. 43, no 3, pp. 476-507. DOI: 10.1007/s11365-018-0526-3.

Chepurenko A., Popovskaya E., Obraztsova O. (2017) Cross-regional Variations in the Motivation of Early-Stage Entrepreneurial Activity in Russia: Determining Factors. Entrepreneurship in transition economies. Diversity, trends, and perspectives (eds. A. Sauka, A. Chepurenko), vol. 23, Heidelberg, Dordrecht, London, New York: Springer, pp. 315-342.

Clark B.R. (1998) The entrepreneurial university: Demand and response. Tertiary Education and Management, vol. 4, no 1, pp. 5-16. DOI: 10.1080/13583883.1998.9966941.

D’Este P., Perkmann M. (2011) Why do academics engage with industry? The entrepreneurial university and individual motivations. Journal of Technology Transfer, vol. 36, no 3, pp. 316-339. DOI: 10.1007/s10961-010-9153-z.

Di Gregorio D., Shane S. (2003) Why do some universities generate more start-ups than others? Research Policy, vol. 32, no 2, pp. 209-227. DOI: 10.1016/S0048-7333(02)00097-5.

Diez J.R. (2000) The Importance of Public Research Institutes in Innovative Networks - Empirical Results from the Metropolitan Innovation Systems. Barcelona, Stockholm and Vienna. European Planning Studies, vol. 8, no 4, pp. 451-463. DOI: $10.1080 / 713666418$.

Elert N., Henrekson M., Stenkula M. (2017) Institutional Reform for Innovation and Entrepreneurship: An Agenda for Europe, Stockholm: Research Institute of Industrial Economics.

Estrin S., Mickiewicz T. (2011) Entrepreneurship in Transition Economies: The Role of Institutions and Generational Change. The Dynamics of Entrepreneurship. Evidence from the Global Entrepreneurship Monitor Data (ed. M. Minniti), Oxford: Oxford University Press, pp. 181-208.

Etzkowitz H. (2001) The Second Academic Revolution and the Rise of Entrepreneurial Science. IEEE Technology and Society Magazine, vol. 20, no 2, pp. 18-29. DOI: 10.1109/44.948843.

Etzkowitz H. (2003) Research groups as 'quasi-firms': The invention of the entrepreneurial university. Research Policy, vol. 32, no 1, pp. 109-121. DOI: 10.1016/S0048-7333(02)00009-4.

Feige E.L. (1997) Underground Activity and Institutional Change: Productive, Protective and Predatory Behavior in Transition Economies. Transforming Post-Communist Political Economies (eds. J.M. Nelson, C. Tilly, L. Walker), Washington, D.C.: National Academy Press, pp. 21-35.

Freytag A., Thurik R. (2007) Entrepreneurship and its determinants in a cross-country setting. Journal of Evolutionary Economics, vol. 17, no 2, pp. 117-131. DOI: 10.1007/s00191-006-0044-2.

Fritsch M., Bublitz E., Sorgner A., Wyrwich M. (2014) How much of a socialist legacy? The re-emergence of entrepreneurship in the East German transformation to a market economy. Small Business Economics, vol. 43, no 2, pp. 427-446. DOI: $10.1007 /$ s11187-014-9544-x.

Fritsch M., Storey D.J. (2014) Entrepreneurship in a Regional Context: Historical Roots, Recent Developments and Future Challenges. Regional Studies, vol. 48, no 6, pp. 939-954. DOI: 10.1080/00343404.2014.892574.

Fritsch M., Titze M., Piontek M. (2018) Knowledge interactions in regional innovation networks: Comparing data sources (Jena Economic Research Paper 2018-003), Jena: Friedrich-Schiller-University Jena. Available at: http://hdl.handle. net/10419/174380, accessed 13.03.2019.

Fritsch M., Wyrwich M. (2014) The Long Persistence of Regional Levels of Entrepreneurship: Germany, 1925-2005. Regional Studies, vol. 48, no 6, pp. 955-973. DOI: 10.1080/00343404.2013.816414.

Fritsch M., Wyrwich M. (2017a) The effect of entrepreneurship on economic development - An empirical analysis using regional entrepreneurship culture. Journal of Economic Geography, vol. 17, no 1, pp. 157-189. DOI: 10.1093/jeg/lbv049.

Fritsch M., Wyrwich M. (2017b) Persistence of Regional Entrepreneurship: Causes, Effects, and Directions for Future Research. International Review of Entrepreneurship, vol. 15, no 4, pp. 395-416.

Froumin I., Kouzminov Y., Semyonov D. (2014) Institutional diversity in Russian higher education: Revolutions and evolution. European Journal of Higher Education, vol. 4, no 3, pp. 209-234. DOI: 10.1080/21568235.2014.916532.

Fuster E., Padilla-Meléndez A., Lockett N., del-Águila-Obra A.R. (2019) The emerging role of university spin-off companies in developing regional entrepreneurial university ecosystems: The case of Andalusia. Technological Forecasting and Social Change, vol. 141, pp. 219-231. DOI: 10.1016/j.techfore.2018.10.020.

Gershman M., Gokhberg L., Kuznetsova T., Roud V. (2018) Bridging S\&T and innovation in Russia: A historical perspective. Technological Forecasting and Social Change, vol. 133, pp. 132-140. DOI: 10.1016/j.techfore.2018.03.014. 
Ghio N., Guerini M., Rossi-Lamastra C. (2019) The creation of high-tech ventures in entrepreneurial ecosystems: exploring the interactions among university knowledge, cooperative banks, and individual attitudes. Small Business Economics, vol. 52, no 2, pp. 523-543. DOI: 10.1007/s11187-017-9958-3.

Gianiodis P.T., Markman G.D., Panagopoulos A. (2016) Entrepreneurial universities and overt opportunism. Small Business Economics, vol. 47, no 3, pp. 609-631. DOI: 10.1007/s11187-016-9753-6.

Goethner M., Wyrwich M. (2017) Cross-faculty proximity and academic entrepreneurship: The role of business schools (Jena Economic Research Paper 2017-017), Jena: Friedrich-Schiller-University Jena. Режим доступа: http://hdl.handle. net/10419/174377, дата обращения 13.03.2019.

Gokhberg L. (2004) Russia's National Innovation System and the "New Economy". Problems of Economic Transition, vol. 46, no 9, pp. 8-34. DOI: 10.1080/10611991.2004.11049870.

Gokhberg L., Kuznetsova T. (2011) S\&T and Innovation in Russia: Key Challenges of the Post-Crisis Period. Journal of EastWest Business, vol. 17, no 2-3, pp. 73-89. DOI: 10.1080/10669868.2011.634769.

Graf H. (2011) Gatekeepers in regional networks of innovators. Cambridge Journal of Economics, vol. 35, no 1, pp. $173-198$.

Grimpe C., Fier H. (2010) Informal university technology transfer: A comparison between the United States and Germany. Journal of Technology Transfer, vol. 35, no 6, pp. 637-650. DOI: 10.1007/s10961-009-9140-4.

Guerrero M., Urbano D., Fayolle A., Klofsten M., Mian S. (2016) Entrepreneurial universities: Emerging models in the new social and economic landscape. Small Business Economics, vol. 47, no 3, pp. 551-563. DOI: 10.1007/s11187-016-9755-4.

Gurvich E. (2016) Institutional constraints and economic development. Russian Journal of Economics, vol. 2, no 4, pp. 349374. DOI: $10.1016 /$ j.ruje.2016.11.002.

Hassink R., Wood M. (1998) Geographic 'clustering' in the German opto electronics industry. Entrepreneurship \& Regional Development, vol. 10, no 4, pp. 277-296. DOI: 10.1080/08985629800000016.

Heller R. (2013) The Russian Innovation Ecosystem 2013. International Journal of Innovation Science, vol. 5, no 2, pp. 119-130. DOI: 10.1260/1757-2223.5.2.119.

Hewitt-Dundas N. (2013) The role of proximity in university-business cooperation for innovation. Journal of Technology Transfer, vol. 38, no 2, pp. 93-115. DOI: 10.1007/s10961-011-9229-4.

Kauffeld-Monz M., Fritsch M. (2013) Who Are the Knowledge Brokers in Regional Systems of Innovation? A Multi-Actor Network Analysis. Regional Studies, vol. 47, no 5, pp. 669-685. DOI: 10.1080/00343401003713365.

Keeble D., Lawson C., Smith H.L., Moore B., Wilkinson F. (1998) Internationalisation Processes, Networking and Local Embeddedness in Technology-Intensive Small Firms. Small Business Economics, vol. 11, no 4, pp. $327-342$. DOI: 10.1023/A:1007942612220.

Korobkov A., Zayonchkovskaya Z.A. (2012) Russian brain drain: Myths v. reality. Communist and Post-Communist Studies, vol. 45, no 3-4, pp. 327-341.

Korosteleva J., Belitski M. (2017) Entrepreneurial dynamics and higher education institutions in the post-Communist world. Regional Studies, vol. 51, no 3, pp. 439-453. DOI: 10.1080/00343404.2015.1103370.

Kutsenko E., Meissner D. (2013) Key Features of the First Phase of the National Cluster Program in Russia (HSE Working Paper WP BRP 11/STI/2013), Moscow: HSE. Available at: http://www.clusterobservatory.eu/eco/uploaded/pdf/1366786413378. pdf, accessed 15.02.2019.

Lamberova N., Sonin K. (2018) Economic transition and the rise of alternative institutions. Economics of Transition, vol. 26, no 4, pp. 615-648. DOI: 10.1111/ecot.12167.

Leyden D.P., Link A.N. (2013) Knowledge spillovers, collective entrepreneurship, and economic growth: The role of universities. Small Business Economics, vol. 41, no 4, pp. 797-817. DOI: 10.1007/s11187-013-9507-7.

Lockett A., Siegel D., Wright M., Ensley M.D. (2005) The creation of spin-off firms at public research institutions: Managerial and policy implications. Research Policy, vol. 34, no 7, pp. 981-993.

Manolova T.S., Eunni R.V., Gyoshev B.S. (2008) Institutional Environments for Entrepreneurship: Evidence from Emerging Economies in Eastern Europe. Entrepreneurship Theory and Practice, vol. 32, no 1, pp. 203-218. DOI: 10.1111/j.15406520.2007.00222.x.

McMillan J., Woodruff C. (2002) The Central Role of Entrepreneurs in Transition Economies. Journal of Economic Perspectives, vol. 16, no 3, pp. 153-170. DOI: 10.1257/089533002760278767.

Meissner D. (2018) Entrepreneurial Universities: Towards a Revised Paradigm // Innovation and the Entrepreneurial University (eds. D. Meissner, E. Erdil, J. Chataway), Heildelberg, Dordrecht, London, New York: Springer, pp. 37-55.

Meissner D., Shmatko N. (2017) "Keep open": The potential of gatekeepers for the aligning universities to the new Knowledge Triangle. Technological Forecasting and Social Change, vol. 123, pp. 191-198. DOI: 10.1016/j.techfore.2016.03.012.

Mueller S.L., Thomas A.S. (2001) Culture and entrepreneurial potential. Journal of Business Venturing, vol. 16, no 1, pp. 51-75. DOI: $10.1016 /$ S0883-9026(99)00039-7.

North D.C. (1990) Institutions, Institutional Change and Economic Performance, Cambridge: Cambridge University Press.

OECD (2019) Local entrepreneurship ecosystems and emerging industries: Case study of Malopolskie, Poland (LEED Working Paper 03), Paris: OECD. Available at: https://www.oecd-ilibrary.org/industry-and-services/local-entrepreneurship-ecosystems-and-emerging-industries-case-study-of-malopolskie-poland_d99ba985-en, accessed 16.05.2019. 
O’Shea R.P., Allen T.J., Chevalier A., Roche F. (2005) Entrepreneurial orientation, technology transfer and spinoff performance of U.S. universities. Research Policy, vol. 34, no 7, pp. 994-1009.

Ovaska T., Sobel R. (2005) Entrepreneurship in Post-Socialist Economies. Journal of Private Enterprise, vol. 21, issue Fall, pp. 8-28.

Perkmann M., Tartari V., McKelvey M., Autio E., Broström A., D’Este P., Fini R., Geuna A., Grimaldi R., Hughes A., Krabel S., Kitson M., Llerena P., Lissoni F., Salter A., Sobrero M. (2013) Academic engagement and commercialisation: A review of the literature on university-industry relations. Research Policy, vol. 42, no 2, pp. 423-442. DOI: 10.1016/j.respol.2012.09.007.

Polterovich V. (2017) Institutional Trap. The New Palgrave Dictionary of Economics (eds. L.E. Blume, S.N. Durlauf), London: Palgrave Macmillan, pp. 1-7. Available at: https://www.researchgate.net/publication/311907319_Institutional_Trap, accessed 12.04.2019.

Powers J.B., McDougall P.P. (2005) University start-up formation and technology licensing with firms that go public: A resource-based view of academic entrepreneurship. Journal of Business Venturing, vol. 20, no 3, pp. 291-311.

Rothaermel F.T., Agung S.D., Jiang L. (2007) University entrepreneurship: A taxonomy of the literature. Industrial and Corporate Change, vol. 16, no 4, pp. 691-791. DOI: 10.1093/icc/dtm023.

Roundy P.T. (2017) Hybrid organizations and the logics of entrepreneurial ecosystems. International Entrepreneurship and Management Journal, vol. 13, no 4, pp. 1221-1237. DOI: 10.1007/s11365-017-0452-9.

Roundy P.T., Fayard D. (2019) Dynamic Capabilities and Entrepreneurial Ecosystems: The Micro-Foundations of Regional Entrepreneurship. The Journal of Entrepreneurship, vol. 28, no 1, pp. 94-120. DOI: 10.1177/0971355718810296.

Sauka A., Chepurenko A.Yu. (eds.) (2017) Entrepreneurship in transition economies: Diversity, trends, and perspectives, Heidelberg, Dordrecht, London, New York: Springer.

Sauka A., Welter F. (2007) Productive, unproductive and destructive entrepreneurship in an advanced transition setting: The example of Latvian small enterprises. Empirical entrepreneurship in Europe. New perspectives (eds. M.J. Dowling, J. Schmude), Cheltenham: Edward Elgar, pp. 87-105.

Schätzl L. (1999) Regionen: Kompetenzzentren und Globalisierung. Vision und Verantwortung. Herausforderungen an der Schwelle zum neuen Jahrtausend (eds. H. Hesse, B. Rebe), Hildesheim: Olms, pp. 97-107.

Schubert T., Kroll H. (2016) Universities' effects on regional GDP and unemployment: The case of Germany. Papers in Regional Science, vol. 95, no 3, pp. 467-489. DOI: 10.1111/pirs.12150.

Shane S. (2004) Academic entrepreneurship: University spinoffs and wealth creation, Cheltenham: Edward Elgar.

Sivak E., Yudkevich M.M. (2017) The academic profession in Russia’s two capitals: The impact of 20 years of transition. European Educational Research Journal, vol. 16, no 5, pp. 626-644.

Smallbone D., Welter F. (2001) The Distinctiveness of Entrepreneurship in Transition Economies. Small Business Economics, vol. 16, no 4, pp. 249-262. DOI: 10.1023/A:1011159216578.

Smallbone D., Welter F. (2006) Conceptualising entrepreneurship in a transition context. International Journal of Entrepreneurship and Small Business, vol. 3, no 2, pp. 190-206. DOI: 10.1504/IJESB.2006.008928.

Smolentseva A., Huisman J., Froumin I. (2018) Transformation of Higher Education Institutional Landscape in Post-Soviet Countries: From Soviet Model to Where? 25 Years of Transformations of Higher Education Systems in Post-Soviet Countries. Reform and Continuity (eds. J. Huisman, A. Smolentseva, I. Froumin), Basingstoke: Palgrave Macmillan, pp. 1-43.

Sorenson O. (2017) Regional ecologies of entrepreneurship. Journal of Economic Geography, vol. 17, no 5, pp. 959-974. DOI: $10.1093 /$ jeg/lbx031.

Sosnovskikh S. (2017) Industrial clusters in Russia: The development of special economic zones and industrial parks. Russian Journal of Economics, vol. 3, no 2, pp. 174-199. DOI 10.1016/j.ruje.2017.06.004.

Spigel B. (2017) The Relational Organization of Entrepreneurial Ecosystems. Entrepreneurship Theory and Practice, vol. 41, no 1, pp. 49-72. DOI: 10.1111/etap.12167.

Stam E. (2014) The Dutch Entrepreneurial Ecosystem. SSRN Electronic Journal. Available at: https://papers.ssrn.com/sol3/ papers.cfm?abstract_id=2473475, accessed 15.06.2019.

Stam E. (2015) Entrepreneurial Ecosystems and Regional Policy: A Sympathetic Critique. European Planning Studies, vol. 23, no 9, pp. 1759-1769. DOI: 10.1080/09654313.2015.1061484.

Stuetzer M., Audretsch D.B., Obschonka M., Gosling S.D., Rentfrow P.J., Potter J. (2018) Entrepreneurship culture, knowledge spillovers and the growth of regions. Regional Studies, vol. 52, no 5, pp. 608-618. DOI: 10.1080/00343404.2017.1294251.

Szerb L., Trumbull W.N. (2018) Entrepreneurship development in Russia: Is Russia a normal country? An empirical analysis. Journal of Small Business and Enterprise Development, vol. 25, no 6, pp. 902-929. DOI: 10.1108/JSBED-01-2018-0033.

Thursby J.G., Thursby M.C. (2002) Who Is Selling the Ivory Tower? Sources of Growth in University Licensing. Management Science, vol. 48, no 1, pp. 90-104. DOI: 10.1287/mnsc.48.1.90.14271.

Ulhøi J., Neergaard H., Bjerregaard T. (2012) Beyond Unidirectional Knowledge Transfer. International Journal of Entrepreneurship and Innovation, vol. 13, no 4, pp. 287-299. DOI: 10.5367/ijei.2012.0093.

Velt H., Torkkeli L., Saarenketo S. (2018) The entrepreneurial ecosystem and born globals: The Estonian context. Journal of Enterprising Communities, vol. 12, no 2, pp. 117-138. DOI: 10.1108/JEC-08-2017-0056. 
Volchek D., Henttonen K., Edelmann J. (2013) Exploring the Role of a Country's Institutional Environment in Internationalization: Strategic Responses of SMEs in Russia. Journal of East-West Business, vol. 19, no 4, pp. 317-350. DOI: $10.1080 / 10669868.2013 .851140$.

Welter F. (2005) Entrepreneurial Behaviour in Differing Environments. Local Heroes in the Global Village. Globalization and the New Entrepreneurship Policies (eds. D. Audretsch, H. Grimm, C.W. Wessner), Boston, MA: Springer Science, Business Media Inc, pp. 93-112.

Welter F. (2011) Contextualizing Entrepreneurship-Conceptual Challenges and Ways Forward. Entrepreneurship Theory and Practice, vol. 35, no 1, pp. 165-184. DOI: 10.1111/j.1540-6520.2010.00427.x.

Wyrwich M. (2012) Regional Entrepreneurial Heritage in a Socialist and a Postsocialist Economy. Economic Geography, vol. 88, no 4, pp. 423-445. DOI: 10.1111/j.1944-8287.2012.01166.x.

Wyrwich M. (2013) Can socioeconomic heritage produce a lost generation with regard to entrepreneurship? Journal of Business Venturing, vol. 28, no 5, pp. 667-682.

Wyrwich M. (2015) Entrepreneurship and the intergenerational transmission of values. Small Business Economics, vol. 45, no 1, pp. 191-213. DOI: $10.1007 /$ s11187-015-9649-x.

Yudkevich M.M. (2014) The Russian University: Recovery and Rehabilitation. Studies in Higher Education, vol. 39, no 8, pp. 1463-1474.

Yukhanaev A., Fallon G., Baranchenko Y., Anisimova A. (2015) An Investigation into the Formal Institutional Constraints that Restrict Entrepreneurship and SME Growth in Russia. Journal of East-West Business, vol. 21, no 4, pp. 313-341. DOI: $10.1080 / 10669868.2015 .1092190$.

Zahra S.A., Nambisan S. (2012) Entrepreneurship and strategic thinking in business ecosystems. Business Horizons, vol. 55, no 3, pp. 219-229. DOI: 10.1016/j.bushor.2011.12.004.

Zhuplev A., Shtykhno D. (2009) Motivations and Obstacles for Small Business Entrepreneurship in Russia: Fifteen Years in Transition. Journal of East-West Business, vol. 15, no 1, pp. 25-49. DOI: 10.1080/10669860902900347. 